\title{
Effect Of Spirulina Platensis on The Number of Spermatogenic Cells in The Seminiferous Tubules of Rat (Rattus Norvegicus) with Excessive
Physical Exercise
}

\author{
Rahmah Wahyu Rosidawati ${ }^{1}$, Rimayanti ${ }^{2}$, and Koesnoto Supranianondo ${ }^{3}$ \\ ${ }^{1}$ Student \\ ${ }^{2}$ Departement of Veterinary Reproduction \\ ${ }^{3}$ Departement of Livestock \\ Faculty of Veterinary Medicine - Universitas Airlangga \\ Kampus C UNAIR, Jalan Mulyorejo,Surabaya-60115
}

Corresponding Author:

Rimayanti

rima_irmansyah@yahoo.co.id

Received: 03 October 2017

Accepted: 10 October 2017

Published: 29 November 2017

Publishing services provided

by Knowledge E

(c) Rahmah Wahyu Rosidawati et al. This article is distributed under the terms of the

Creative Commons Attribution

License, which permits

unrestricted use and

redistribution provided that

the original author and source are credited.

Selection and Peer-review under the responsibility of the VMIC Conference Committee.

\section{Abstract}

The aim of this study was to investigate the effect of Spirulina platensis extract on the number of spermatogenic cells of rats with excessive physical exercise. Excessive physical exercise was achieved through one hour of swimming for 35 days. Twenty male rats were divided into five groups i.e (1) C-, control group, (2) C+, a group was only given swimming, (3) $\mathrm{T} 1$, a group was given $300 \mathrm{mg} / \mathrm{kg}$ BW of Spirulina platensis and swimming, (4) T2, a group was given $600 \mathrm{mg} / \mathrm{kg}$ BW of Spirulina platensis and swimming, and (5) T3, a group was given $1200 \mathrm{mg} / \mathrm{kg}$ BW of Spirulina platensis and swimming. Spirulina platensis extract was given orally once a day before swimming. ANOVA test followed with Duncan test showed that the number of spermatogenic cells significantly different among treatments $(p<0.05)$. Excessive physical exercise was able to influence on the male reproduction system by declined on the number of spermatogenic cells in seminiferous tubules of male rat. The conclusion of this study was dose of $1200 \mathrm{mg} / \mathrm{kg} \mathrm{BW}$ of Spirulina platensis extract could maintain the number of spermatogenic cells of male rat after excessive physical exercise.

Keywords: Rattus norvegicus, Spirulina platensis, excesive physical exercise, spermatogenic cells.

\section{Introduction}

Physical exercise is needed by human and animal to maintain good health, as the result, it can prevent some risk on disease later. Regular physical exercise gives good effect for body which can prevent and treat many chronic disease, such as coronary 
heart disease (CHD), hypertension, heart failure, obesity, depression, diabetes mellitus, cancers and osteoporosis (Haskell et al., 2007; Oja and Sylvia, 2011), but if the physical exercise is excessive, it can give many disadvantages for body. The excessive physical exercise can inhibit and disturb the physiologic process in body, thereby the homoestasis of body would be interrupted and caused some disease, such as stroke and coroner heart disease (Chevion et al., 2003; Hairrudin and Dina, 2009).

Excessive physical exercise induce oxidative stress, included increasing of free radical levels in body. In excessive physical exercise, the free radicals formed primaly are Reactive Oxygen Species (De Lima, 2012). Reactive Oxygen Species (ROS) may attack polyunsatured fatty acids on biomembrane, leading a chain of peroxidation reaction, and alter the membrane structure. This reaction can be defined as lipid peroxidation. Lipid peroxidation produce hydrocarbon gases and malondialdehyde (MDA), which this product is the most frequently sign of increasing ROS (Banerjee et al., 2003; Hairrudin et al., 2012; De Lima et al., 2012).

Testicular membrane is rich in polyunsaturated fatty acid and highly risk to oxidative stress (ROS) which leading lipid peroxidation. This condition may cause disturbance function of testes involved spermatogenesis (Manna et al., 2003). Spermatogenesis produce spermatogenic cells included spermatogonia, spermatocyte, spermatid and spermatozoa (Ismudiono et al., 2010). Lipid peroxidation can damage polyunsaturated fatty acid of spermatogenic cells, causing dysfunctional spermatogenic cell and decrease quality of seminiferus tubulus (Laksmi, 2010). Lipid peroxidation also reduced motility of spermatozoa, level of plasma testosterone and LH (Manna et al., 2003).

Spirulina plantesis is a blue-green alga (cyanobacterium) that has been consumed as food and supplement due to its high contents of proteins, linolenic acid, vitamin and mineral. Many research reported the biological activities of Spirulina plantesis as antimicrobial, renoprotector, anti-inflammatory, anticancer, antidiabetic, anti-viral, blood-vessel relaxing effect and hepatoprotective (Mazokopakis et al., 2014). In the research of El-Desoky et al. (2013) showed protective effect of Spirulina plantesis pretreatment could reduce the lipid peroxidation product, mercury accumulation in testis, histopathological changes of testes and spermatozoa abnormalities.

In the present study, an attempt has been made to evaluate the protective potential of Spirulina plantesis against excessive physical exercise to testes of male rats by studying the number of spermatogenic cells in seminiferous tubulus. 
TABLE 1: Effect of Spirulina platensis on the number of spermatogenic cells in seminiferous tubules of male rat with excessive physical exercise (Mean $\pm \mathrm{SD}$ ).

\begin{tabular}{|c|c|c|c|}
\hline Treatment & Spermatogonia & Primary Spermatocyte & Spermatid \\
\hline$C(+)$ & $30.27 \pm 2.86^{a}$ & $25.15 \pm 4.03^{a}$ & $21.05 \pm 3.46^{a}$ \\
\hline$C(-)$ & $62.65 \pm 6.47^{c}$ & $51.25 \pm 5.07^{c}$ & $76.28 \pm 14.88^{c}$ \\
\hline T1 & $42.55 \pm 6.19^{b}$ & $39.63 \pm 5.82^{b}$ & $45.38 \pm 11.88^{b}$ \\
\hline $\mathrm{T}_{2}$ & $46.47 \pm 1.41^{b}$ & $42.00 \pm 5.18^{b}$ & $47.02 \pm 11.86^{b}$ \\
\hline T3 & $56.10 \pm 2.34^{c}$ & $50.65 \pm 3.98^{c}$ & $75.42 \pm 18.88^{c}$ \\
\hline
\end{tabular}

\section{Research Method}

The experimental unit used in this study were 20 healthy male rats (Rattus norvegicus) at age of 2-3 month, and the weight about 150-200 grams. For excessive physical exercise in this study, rats were swam in a bucket with diameter $35 \mathrm{~cm}$, water depth of $20 \mathrm{~cm}$ and water temperature of $32 \circ \mathrm{C}$ for 60 minutes daily (Bhinekada, 2002).

Twenty male rats were divided into five groups. C- groups were received Na-CMC solution, C+ groups were received swimming, T1 were received $300 \mathrm{mg} / \mathrm{kg}$ bw of Spirulina platensis extract and swimming, T2 were received $600 \mathrm{mg} / \mathrm{kg}$ bw of Spirulina platensis extract and swimming and T3 were received $1200 \mathrm{mg} / \mathrm{kg}$ bw of Spirulino platensis extract and swimming. The treatments were administered using $3 \mathrm{ml}$ of syringe with feeding tube by intragastric gavage. Experimental treatment were done everyday for 35 days. 24 hours from the last treatment, all rats were sacrificed by ether anesthesia and the testes were collected.

Evaluation method by counting four different pieces of testicular section from each treatment. Counting were performed on five different seminiferous tubules for each piece of view starts from the corner of the left, right, top, bottom and middle part of the preparations histology.

\section{Result and Discussion}

Analysis of variance test followed with Duncan test had been done to see significant differences between treatment after counting the number of spermatogenic cells in seminiferous tubules male rat. 
The result showed that spermatogenic cells of $C+$ groups had significant differences with $C$ - groups, $T_{1}, T_{2}$ and $T_{3}$ groups $(p<0.05)$. $C$ - groups had significant differences with $\mathrm{T}_{1}$ and $\mathrm{T} 2$ group $(\mathrm{p}<0.05)$. T1 group had no significantly different with T2 group ( $p>0.05)$. T3 groups had significant differences with T1 and T2 group $(p<0.05)$, but had no significant differences with C- group ( $p>0.05$ ).

A group was only given swimming showed the declined of spermatogenic cells in seminiferous tubules male rat (Table 1, Figure 1). It evidenced that excessive physical exercise influenced on male fertility by declined on the number of spermatogenic cells in seminiferous tubules of male rat.

Excessive physical excercise could affect endocrine systems through surpressession of $\mathrm{CRH}$ to $\mathrm{GnRH}$ leading inhibition in anterior pituitary, which was a potent negative regulator of FSH and LH production (Mastorakos et al., 2005). FSH and LH were gonadotropin hormone stimulating spermatogenesis in male reproductive system (Sonjaya, 2012). In addition, excessive physical exercise also affected in production of testosterone leading low concentrations of testosterone. Testosterone itself had important role in growth and development of male reproductive organs, in association with $\mathrm{FSH}$, acts on seminiferous tubules to initiate and maintain spermatogenesis (Saraswathi et al., 2012).

The declined of spermatogenic cells could be associated with enhacement of concentration of ROS causing lipid peroxidation in testicular membrane which was rich of polyunsaturated fatty acid (Manna et al., 2003). High rate of lipid peroxidation could induce apoptosis, leading cell damage (Ayala et al., 2014). The elevation of MDA (ROS product) also could be associated with the reduction of testicular antioxidant scavenger enzyme, such as SOD, CAT, GPx, GST and GSH leading less protection of enzymatic antioxidant in testicular membrane against free radicals (Manna et al., 2003).

In the present study, result of groups which received Spirulina platensis extract and swimming showed enhacement of spermatogenic cells comparing postive control (Table 1, Figure 1). A group received $300 \mathrm{mg} / \mathrm{kg}$ bw and $600 \mathrm{mg} / \mathrm{kg}$ bw of Spirulina platensis extract and swam for 60 minutes had siginificant difference with group which only swam for 60 minutes (Table 1, Figure 1), but it could not maintain the number of spermatogenic cells in seminiferous tubules comparing with normal group (Table 1, Figure 1). It could be indicated that dose of $300 \mathrm{mg} / \mathrm{kg}$ bw and $600 \mathrm{mg} / \mathrm{kg}$ bw of Spirulina platensis extract were not sufficient to protect spermatogenic cells from excessive physical exercise. Meanwhile, a group received $1200 \mathrm{mg} / \mathrm{kg}$ bw of Spirulina platensis extract and swam for 60 minutes had no significant differences with normal (Table 1, Figure 1). It could be indicated that dose of $1200 \mathrm{mg} / \mathrm{kg}$ bw of Spirulina platensis 


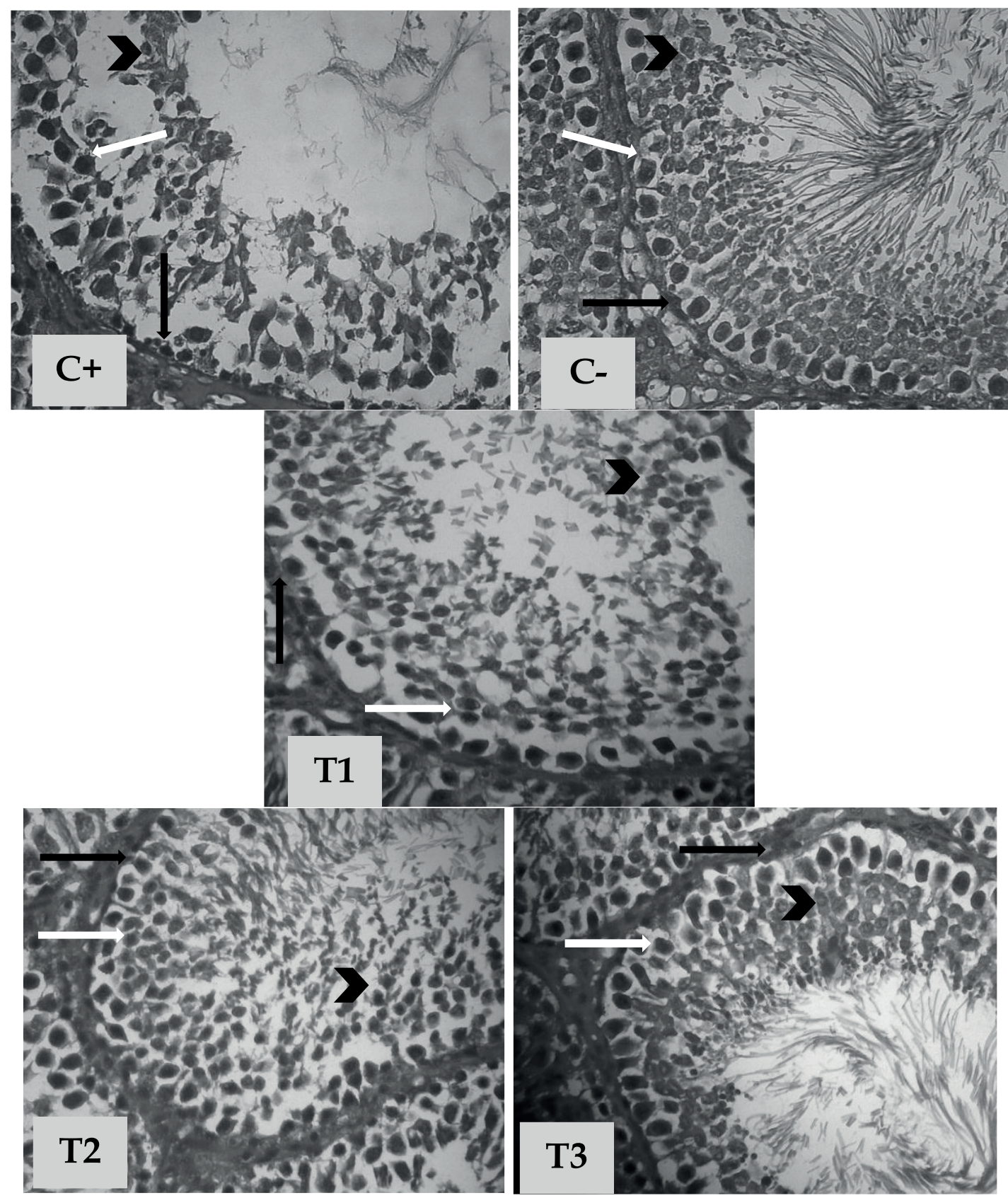

Figure 1: Comparison of histopathological features on seminiferous tubules of rat (Rattus norvegicus) in each groups. Black arrows show the spermatogonia, white arrows show primary spermatocyte, and short arrows show early spermatid. C-= rat received Na-CMC (normal seminiferous tubules), $\mathrm{C}+=$ rat received $\mathrm{Na}-\mathrm{CMC}+$ swimming (spermatogenic cells reduced), $\mathrm{T}_{1}=$ rat received $300 \mathrm{mg} / \mathrm{kg}$ bw of Spirulina platensis +swimming (increased of spermatogenic cells), T2 = rat received $600 \mathrm{mg} / \mathrm{kg}$ bw of Spirulina platensis+swimming (increased of spermatogenic cells), $\mathrm{T}_{3}=$ rat received $1200 \mathrm{mg} / \mathrm{kg}$ bw of Spirulina platensis+swimming (full of spermatogenic cell) (Stain: H.E.; 400x magnification).

extract could maintain on the number of spermatogenic cells in seminiferous tubules male rat. 
Potency of Spirulina platensis to maintain on the number of spermatogenic cells might be associated to the presence of antioxidant activity. The antioxidant and protective effects of Spirulina platensis was owed to their content of antioxidant active constituent such as $C$-phycocyanin, $\beta$-carotene, vitamins, mineral, protein, lipids and carbohydrates (Chu et al., 2010).

C-phycoyanin was the most abundant natural antioxidant from Spirulina platensis, which could scavenge free radicals by adding one atom hidrogen (Estrada et al., 2001). It had been shown that C-phyocyanin could prevent cellular damage occuring as a result of oxidative stress in spermatogenic cells of seminiferous tubules and leydig cells of the stroma (Shaikh et al., 2013).

$\beta$-carotene from Spirulina platensis also had important role to maintain cells from oxidative stress, which could transfer exccessive electron of radical compund into ground state without any chemical change to the $\beta$-carotene. It also reacted with peroxyl radicals that were involved in the oxidation of lipids (Al-Attar, 2009). Previous study of Orazizadeh et al.(2014) showed that supplementation of $\beta$-carotene for 35 days in mice induced by titanium oxide nanoparticles could protect spermatogenesis and cell loss to activity ROS.

Vitamin E and vitamin C in Spirulina platensis could decrease lipid peroxidation in testis. Vitamin E was a chain-breaking antioxidant that prevent the propagation of free radicals in membrane and in plasma lipoprotein. When peroxyl radicals were formed, these react 1000 times faster with vitamin $E$ than with polyunsaturated fatty acid. Meanwhile, vitamin $C$ had the ability to protect against lipid peroxidation by oneelectron reduction of lipid hydroperoxyl radicals (Traber and Stevens, 2011).

Previous study of El-Desoky et al. (2013) showed that Spirulina platensis was able to maintain enzymatic antioxidant,such as SOD, CAT and GPx induced mercuric chloride. SOD and CAT scavenged both extracellular and intracellular superoxide anion and prevents lipid peroxidation of the plasma membrane. In order to act against $\mathrm{H}_{2} \mathrm{O}_{2}, \mathrm{SOD}$ must be conjugated with CAT or GPx. GPx was able to forms an excellent protection against lipid peroxidation of plasma membrane of spermatozoa. It also scavenge $\mathrm{H}_{2} \mathrm{O}_{2}$, which was responsible for the initiation of lipid peroxidation (Dare et al., 2014).

\section{Conclusion}

Based on this research, it could be concluded that excessive physical exercise could influence of male reproduction by reduction on the number of spermatogenic cells in seminiferous tubules of male rat. Spirulina platensis extract could maintain on the 
number of spermatogenic cells in seminiferus tubules of male rat (Rattus norvegicus) with excessive physical exercise. The best dose in this research was $1200 \mathrm{mg} / \mathrm{kg} \mathrm{bw}$ of Spirulina platensis due to its capability to provide the best protection in spermatogenic cells against excessive physical exercise compared to dose of $300 \mathrm{mg} / \mathrm{kg}$ bw of Spirulina platensis and $600 \mathrm{mg} / \mathrm{kg}$ bw of Spirulina platensis

\section{References}

[1] Al-Attar, A.M. 2009. The Ameliorative Role of $\beta$-Carotene Pretreatment on Diazinon-Induced Enzymological and Histopathological Changes in Wistar Male Rats. Global Journal of Pharmacology. 3 (3): 171-177.

[2] Ayala, A., Mario, F.M., and Sandro, A. 2014. Lipid Peroxidation : Production, Metabolism, and Signal mechanisms of Malondialdehyde and 4-hydroxy-2 Nonenal. Oxidative Medicine and Cellular Longevity : 1-31.

[3] Banerjee, A.K., M. Amritlal, C. Dipanjan and C. Sajal. 2003. Oxidant, Antioxidant and Physical Exercise. Molecular and Cellular Biochemistry $253:$ 307-312.

[4] Binekada, M.C. 2002. Pelatihan Fisik Berlebih Menurunkan Konsentrasi dan Motilitas Spermatozoa Mencit (tesis). Universitas Udayana. Denpasar.

[5] Chevion, S., D.S. Moran., Y. Heled., Y. Shani., G. Rege., B. Abbou; E. Berenshtein., E.R. Stadtman, and Y. Epstein. 2003. Plasma antioxidant status and cell injury after severe physical exercise. PNAS. 100 (9) : 5119-5123. Available from : www.pnas.org/cgi/doi/10.1073/pnas.0831097100. Accessed : May, 20 2015.

[6] Chu, W.L, Y.W. Lim, A.K. Radhakrishnan, P.E. Lim. 2010. Protective effect of Aqueous Extract from Spirulina platensis Against Cell Death Induced by Free Radicals. BMC Complementary and Alternative Medicine. 10 (53): 1-8.

[7] Dare, B. J., F. Oyeniyi and O.T. Olaniyan. 2014. Role of Antioxidant in Testicular Integrity. Annual Research and Review in Biology. 4 (7): 998-1023

[8] De Lima, M.C., M. Guido, S.S. Iandara, B.A.K. Da Silva, Z.Z.C. Lourdes and B.N. Gabriel. 2012. Evaluation of Oxidative Stress in Mice Subjected to Aerobic Exrecise. Acta Cirurgica Brasileira. 27 (8): 544-551

[9] El-Desoky, G.E., S.A. Bashandy, I.M. Alhazza, Z.A. Al-Othman, M.A.M. Aboul-Soud and K. Yusuf. 2013. Improvement of Mercuric Chloride-Induced Testis Injuries and Sperm Quality Deteriorations by Spirulina platensis in Rats. PLoS ONE. 8: 1-9.

[10] Estrada, J. E. P., P. B. Bescos and A. M. V. del Fresno. 2001. Antioxidant Activity of Different Fractions of Spirulina platensis Protean Extract. II Farmaco. $56:$ 497-500. 
[11] Hairrudin and H. Dina. 2009. Efek Protektif Propolis Dalam Mencegah Stres Oksidatif Akibat Aktifitas Fisik Berat (Swimming Stress). Jurnal Ilmu Dasar. 10 (2): 207-211.

[12] Hairrudin, H. Dina and W. Yulestrina. 2012. Aktivitas Fisik Berat Menyebabkan Degenerasi Sel Hepatosit melelui Mekanisme Stres Oksidatif. Jurnal kedokteran Brawijaya. 27(2) : 61-65.

[13] Haskel, W.L., I.M. Lee, R.R. Pate, K.E. Powell, S.N. Blair, B.A. Franklin, C.A. Macera, G.W. Heath, P.D. Thompson, A. Bauman. 2007. Physical Activity and Public Health Updated Recommendation for Adults. American College of Sports Medicine and the American Heart Association. Available from : http://circ.ahajournals.org. Accessed : May, $21^{\text {th }} 2015$.

[14] Ismudiono, P. Srianto, H. Anwar, S.P. Madyawati, A. Samik and E. Safitri. 2010. Fisiologi Reproduksi pada Ternak.. Surabaya : Airlangga University Press

[15] Laksmi, D.N.D.I. 2010. Glutathion Meningkatkan Kualitas Tubulus Seminiferus Pada Mencit yang Menerima Pelatihan Fisik Berlebih. Buletin Veteriner Udayana. 2 (1): 11-19

[16] Manna, I., K. Janna and P.K. Samantha. 2003. Effect of Different Intesities of Swimming Exercise on Testicular Oxidative Stress and Reproductive Dysfunction in Mature Male Albino Wistar Rats. Indian Journal of Experimental Biology. 42: 816822.

[17] Mastorakos, G., P. Maria, D.K. Evanthia., P.C. Georga. 2005. Exercise and The Stress System. Hormones. 4(2): 73-89.

[18] Mazokopakis, E.E, G.P. Maria, A.F. Andreas, A.K. Dimitrios, M.L. Loannis, and S.G. Emmanuel. 2014. The Hepatoprotective and Hypolipidemic Effect of Spirulina (Arthrospira platensis) Supplementation in a Cretan Population with non-alcoholic Fatty Liver Diseases : A Prospective Pilot Study. Annals of Gastroenterology. 27:1-8.

[19] Oja, P. and T. Sylvia. 2011. Physical Activity Recomendation for Public Health : Development and Policy Context. EPMA Journal. 2 : 253-259

[20] Orazizadeh, M., L. Khorsandi, F. Absalan, M. Hashemitabar and E. Daneshi. 2014. Effect of Beta-carotene on Titanium Oxide Nanoparticles-induces Testicular Toxicity in Mice. J Assist Reprod Genet. $31: 561-568$

[21] Saraswathi, C.D., M. V. Suresh, S. Sreemantula, and K. Venkata krishna. 2012. Effect of Smillax China Linn On Testicular Antioxidant Activity and Spermatological Parameters in Rats Subjected to Forced Swimming Stress. International Research Journal Of Pharmacy. 3 (11): 118-121. 
[22] Shaikh, H., V.K. Shrivastava., R. Shrivastava., and M. Amir. 2013. Chemo-protective Effect Of Turmeric and Spirulina On Cisplatin Induced Toxicity in Reproductive System of Male Albino Rat, Rattus norvegicus. Indo America Journal of Pharmacentical Research : 7257-7264.

[23] Sonjaya, H. 2012. Dasar Fisiologi ternak. IPB Press. Bogor

[24] Traber, M. G and J. F. Stevens. 2011. Vitamins C and E: Beneficial Effects from a Mechanistic Perspective. Free Radic Bio Med. 51 (5) : 1000-1013. 